\title{
Pengaruh Kesadaran Wajib Pajak, Sanksi, Kualitas Pelayanan dan Sosialisasi pada Kepatuhan Wajib Pajak Kendaraan Bermotor
}

\author{
Ni Putu Atik Widiastini1 \\ Fakultas Ekonomi Dan Bisnis \\ Universitas Udayana, Indonesia \\ Email: atik11.aw@gmail.com
}

\author{
Ni Luh Supadmi² \\ Fakultas Ekonomi Dan Bisnis \\ Universitas Udayana, Indonesia
}

\begin{abstract}
ABSTRAK
Pajak kendaraan bermotor merupakan pajak atas kepemilikan dan atau penguasaan kendaraan bermotor. Tujuan dari penelitian ini adalah untuk mengetahui pengaruh kesadaran wajib pajak, sanksi perpajakan, kualitas pelayanan dan sosialisasi perpajakan pada kepatuhan wajib pajak dalam membayar pajak kendaraan bermotor di Kota Denpasar. Penelitian ini berlokasi di Kantor Bersama SAMSAT Kota Denpasar. Jumlah sampel yang digunakan adalah 100 wajib pajak kendaraan bermotor yang dihitung menggunakan rumus slovin dengan metode penentuansampel adalah accidental sampling. Teknik analisis data yang digunakan adalah analisis regresi linear berganda. Hasil penelitian ini menunjukkan bahwa kesadaran wajib pajak, sanksi perpajakan, kualitas pelayanan dan sosialisasi perpajakan berpengaruh positif pada kepatuhan wajib pajak dalam membayar pajak kendaraan bermotor di Kantor Bersama SAMSAT Denpasar.
\end{abstract}

Kata Kunci: Kesadaran Wajib Pajak; Sanksi; Kualitas Pelayanan; Sosialisasi; Kepatuhan.

\section{Effects of Taxpayer Awareness, Tax Sanctions, Service Quality and Tax Information Dissemination on Taxpayer Compliance in Paying Motorized Vehicle Taxes}

\section{ABSTRACT}

Motor vehicle tax is a tax on the ownership and / or control of motor vehicles. The purpose of this study is to obtain empirical evidence of the influence of taxpayer awareness, tax sanctions, service quality and tax information dissemination on tax compliance in paying motor vehicle tax in Denpasar. This research is located in the Joint Office SAMSAT Denpasar City. The number of samples used was 100 motor vehicle taxpayers which were calculated using the Slovin formula with the sample determination method used was accidental sampling. The data analysis technique used is multiple linear regression analysis. The results of this study indicate that taxpayer awareness, tax sanctions, service quality and tax socialization have a positive effect on taxpayer compliance in paying motor vehicle tax at the Joint Office of SAMSAT Denpasar.

Keywords: Taxpayer Awareness; Penalty; Service quality; Socialization; Obedience.

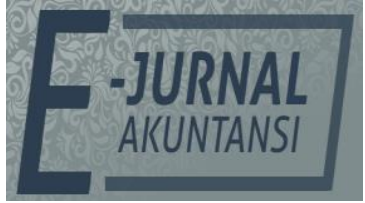

E-JA

e-Jurnal Akuntansi e-ISSN 2302-8556

Vol. 30 No. 7

Denpasar, Juli 2020

Hal.1645-1657

Artikel Masuk:

2 Januari 2020

Tanggal Diterima: 16 Juni 2020

This Article is Avalilable in: $h t t p s: / / o j s . u n u d . a c . i d / i n d e x . p h p / A k u n t a n s i / i n d e x$ 


\section{PENDAHULUAN}

Pajak adalah kontribusi wajib kepada Negara berdasarkan undang-undang yang bersifat memaksa berupa iuran yang dibayarkan untuk membiayai berbagai pengeluaran negara dan tidak mendapatkan imbalan dari negara secara langsung. Berdasarkan atas kewenangan, pemungutan pajak dibedakan menjadi dua yaitu pajak pusat dan pajak daerah. Pajak merupakan salah satu sumber pendapatan asli daerah yang menjadi sumber pembiayaan pembangunan daerah (Nirajenani \& Lely, 2018).

Penelitian ini difokuskan pada salah satu jenis Pajak Daerah yaitu Pajak Kendaraan Bermotor (PKB). Pajak kendaraan bermotor merupakan pajak atas kepemilikan dan/atau penguasan kendaraan bermotor. Instansi yang bertugas memproses pelunasan Pajak Kendaraan Bermotor yakni Dinas Pendapatan Daerah (Dispenda) melalui Kantor Bersama Sistem Administrasi Menunggal di Bawah Satu Atap (SAMSAT) yang merupakan kejasama tiga instansi terkait, diantaranya Dispenda Provinsi Bali, Kepolisian RI dan Asuransi Jasa Raharja. Dalam mendanai pembangunan daerah, PKB merupakan satu dari beberapa pajak daerah dengan potensi yang dominan. Pengembangan daerah di kabupaten atau kota didanai dari pajak kendaraan bermotor karena itulah pemerintah daerah mengoptimalkan pemungutan pajak kendaraan bermotor (Dharma \& Suardana, 2014)

Data Dinas Pendapatan Provinsi Bali menyatakan jumlah kendaraan bermotor di Provinsi Bali meningkat setiap tahunnya. Kota Denpasar memiliki jumlah kendaraan bermotor terbanyak dibandingkan dengan delapan kabupaten lainnya. Secara berturut-turut selama lima tahun terakhir yaitu tahun 2014, 2015, 2016, 2017, dan 2018. Berdasarkan data Realisasi Pendapatan Daerah Provinsi Bali yang bersumber dari Bank Indonesia, realisasi PAD Provinsi Bali pada tahun 2018 mencapai Rp 3,70 triliun atau 103,79 persen, pendapatan didominasi oleh komponen pajak daerah yaitu sub komponen Pajak Kendaraan Bermotor dan sub komponen Bea Balik Nama Kendaraan Bermotor. Kondisi ini sejalan dengan Karakteristik Bali sebagai daerah destinasi utama wisata Dunia, sehingga kebutuhan sarana transportasi (kendaraan bermotor) sangat tinggi. Dengan adanya peningkatan yang signifikan secara terus-menerus tahun 2014-2018 pada realisasi dan tunggakan pajak kendaraan bermotor inilah yang membuat peneliti tertarik untuk melakukan penelitian mengenai faktor-fator yang memengaruhi kepatuhan wajib pajak dalam membayar pajak kendaraan bermotor di Kota Denpasar.

Berdasarkan pada penelitian sebelumnya terdapat beberapa faktor yang dapat memengaruhi kepatuhan wajib pajak dalam membayar kewajiban perpajakannya antara lain kesadaran wajib pajak, sanksi perpajakan, kualitas pelayanan dan sosialisasi perpajakan. Kesadaran wajib pajak dapat dilihat dari kesungguhan dan keinginan wajib pajak untuk memenuhi kewajiban pajaknya yang ditunjukkan dalam pemahaman wajib pajak terhadap fungsi pajak dan kesungguhan wajib pajak dalam membayar pajak. Semakin tinggi tingkat kesadaran Wajib Pajak, maka pemahaman dan pelaksanaan kewajiban perpajakan semakin baik sehingga dapat meningkatkan kepatuhan (Astana \& Lely, 2017). Jika dilihat dari jumlah tunggakan dan denda Pajak Kendaraan Bermotor di Kantor Samsat Denpasar, kesadaran wajib pajak masih 
dikatakan rendah. Guna meningkatkan kepatuhan wajib pajak, kesadaran wajib pajak mengenai perpajakan sangatlah diperlukan (Jotopurnomo \& Mangoting, 2013)

Selain kesadaran Wajib Pajak, terdapat faktor lain yang memengaruhi tingkat kepatuhan Wajib Pajak yaitu sanksi perpajakan. Sanksi perpajakan merupakan jaminan bahwa ketentuan perundang-undangan perpajakan (norma perpajakan) akan dituruti, ditaati dan dipatuhi. Sanksi perpajakan merupakan alat pencegah agar wajib pajak tidak melanggar norma perpajakan (Mardiasmo, 2016:62). (Mardiasmo, 2016:62) menyatakan sanksi perpajakan merupakan jaminan bahwa ketentuan peraturan perundang-undangan perpajakan (norma perpajakan) akan dituruti, ditaati, dipatuhi atau bisa dengan kata lain sanksi perpajakan merupakan alat pencegah (preventif) agar wajib pajak tidak melanggar norma perpajakan.

Kualitas pelayanan menjadi salah satu faktor yang mempengaruhi kepatuhan dari wajib pajak. Memberikan pelayanan yang baik dapat meningkatkan kepatuhan dari wajib pajak Rajif (2012). Direktorat Jenderal Pajak mengupayakan sosialisasi perpajakan untuk memberikan pengertian, informasi, dan pembinaan kepada masyarakat pada umumnya dan wajib pajak pada khususnya mengenai segala sesuatu yang berhubungan dengan perpajakan dan perundang-undangan (Nirajenani \& Lely, 2018). Sosialisasi perpajakan berpengaruh secara signifikan terhadap kepatuhan Wajib Pajak. Melalui sosialisasi perpajakan WP akan mengerti dan mengetahui pentingnya peran pajak untuk pembangunan suatu Negara, serta pentingnya pajak bagi kemajuan suatu bangsa Kurniawan (2006).

Penelitian sebelumnya menunjukkan hasil yang berbeda antara peneliti mengenai pengaruh Kesadaraan wajib pajak terhadap kepatuhan wajib pajak. Penelitian Putri (2013) membuktikan bahwa kesadaran wajib pajak berpengaruh positif terhadap kepatuhan wajib pajak dalam membayar pajak. Peneltian Putri (2013) menyatakan bahwa kesadaran wajib pajak tidak berpengaruh signifikan terhadap kepatuhan wajib pajak. Penelitian (Winerungan, 2012) yang menemukan bahwa sanksi pajak tidak memberikan pengaruh terhadap perubahan kepatuhan wajib pajak orang pribadi dari masyarakat. Hasil pengujian ini berbeda dengan penelitian yang dilakukan Tiraada (2013), bahwa sanksi perpajakan berpengaruh signifikan terhadap kepatuhan wajib pajak orang pribadi, disebabkan karena sanksi pajak diberlakukan secara tegas. Penelitian yang dilakukan oleh Nirajenani (2018) dan Utama (2013) menunjukkan bahwa Kualitas pelayanan memiliki pengaruh positif dan signifikan pada kepatuhan wajib pajak kendaraan bermotor.

Meningkatnya kesadaran wajib pajak seiring dengan tingkat kepatuhan wajib pajak. Semakin tinggi tingkat kesadaran dari wajib pajak untuk membayar kewajibannya, maka semakin tinggi pula tingkat kepatuhan dari wajib pajak tersebut. Sedangkan apabila tingkat kesadaran wajib pajak untuk membayar kewajiban pajaknya rendah, maka semakin rendah pula tingkat kepatuhan dari wajib pajak tersebut. Tentunya semakin sadar wajib pajak untuk membayar kewajiban pajaknya akan secara otomatis mendorong tingkat kepatuhan wajib pajak tersebut. Penelitian Pujiasti (2016) dan Nirajenani (2018) membuktikan bahwa kesadaran wajib pajak berpengaruh positif dan signifikan terhadap 
kepatuhan wajib pajak dalam membayar pajak. Hasil tersebut menunjukkan bahwa wajib pajak yang memiliki kesadaran akan lebih patuh dalam melakukan kewajiban pajak kendaraan bermotornya, maka hipotesis yang disajikan seperti berikut.

$\mathrm{H}_{1}$ : Kesadaran wajib pajak berpengaruh positif pada kepatuhan wajib pajak dalam membayar Pajak Kendaraan Bermotor di Kantor SAMSAT Kota Denpasar.

Berdasarkan Theory of Planned Behavior, sanksi administrasi terkait dengan perceived behavioral control karena sanksi dibuat untuk mendukung wajib pajak agar mematuhi peraturan administrasi perpajakan. Sanksi pajak merupakan jaminan bahwa ketentuan peraturan perundangan-undangan perpajakan akan ditaati. Kepatuhan wajib pajak akan ditentukan berdasarkan presepsi wajib pajak tentang seberapa kuat sanksi perpajakan mempengaruhi perilaku wajib untuk taat pajak. Pemerintah membuat sanksi perpajakan untuk menigkatkan kepatuhan wajib pajak. Sanksi pajak merupakan suatu reaksi yang diberikan kepada wajib pajak yang tidak melaksanakan kewajiban pajaknya sebagaimana mestinya dengan kata lain sanksi pajak juga diberikan untuk melihat respon dari seorang wajib pajak dalam melaksanakan kewajiban pajaknya. Sanksi pajak yang diberikan pada pelanggar pajak tentunya merupakan peraturan yang telah diatur dalam undang-undang perpajakan. (Webley et al., 1991) menyatakan bahwa untuk mencegah ketidakpatuhan dan untuk mendorong wajib pajak untuk memenuhi kewajiban perpajakannya, maka haruslah diberlakukan sanksi yang tegas dalam rangka untuk memajukan keadilan dan efektivitas sistem perpajakan. Menurut (Mardiasmo, 2016:62) menyatakan bahwa Sanksi perpajakan merupakan jaminan bahwa ketentuan perundang-undangan perpajakan (norma perpajakan) akan dituruti/ditaati/dipatuhi at au bisa dengan kata lain sanksi perpajakan merupakan alat pencegahan (preventif) agar wajib pajak tidak melanggar norma perpajakan. Terdapat dua jenis sanksi dalam Undang-undang perpajakan, yaitu sanksi pidana dan sanksi administrasi. Menurut Peraturan Daerah (Perda) Provinsi Bali Nomor 1 Tahun 2011 tentang Pajak Daerah menyatakan bahwa seorang wajib pajak akan dikenai sanksi apabila wajib pajak tersebut tidak melaksanakan kewajibannya dalam membayar pajak, adapun sanksi yang akan dikenakan yaitu wajib pajak akan membayar denda sebesar 25\% (dua puluh lima persen) dari pokok pajak.

Penelitian yang dilakukan (Ilhamsyah et al., 2016) menemukan bahwa sanksi pajak berpengaruh signifikan terhadap kepatuhan wajib pajak kendaraan bermotor yang terdaftar di Kantor Bersama SAMSAT Kota Malang Penelitian dari Angraini (2018) juga membuktikan bahwa sanksi perpajakan berpengaruh positif terhadap kepatuhan wajib pajak di Kantor Bersama SAMSAT Kota Palembang, maka hipotesis yang disajikan seperti berikut.

$\mathrm{H}_{2}$ : Sanksi perpajakan berpengaruh positif pada kepatuhan wajib pajak dalam membayar Pajak Kendararaan Bermotor di Kantor SAMSAT Kota Denpasar.

Theory of planned behavior digunakan untuk menjelaskan perilaku wajib pajak dalam memenuhi kewajiban perpajakannya. Normative beliefs, yaitu seseorang akan memiliki keinginan untuk berperilaku jika memiliki kepercayaan mengenai harapan normatif orang lain dan memiliki dorongan 
untuk mewujudkan harapan tersebut. Upaya dalam peningkatan kepatuhan wajib pajak dapat dilakukan dengan meningkatkan kualitas pelayanan yang baik kepada wajib pajak. Pelayanan yang berkualitas terhadap wajib pajak adalah usaha yang dilakukan petugas pajak untuk melayani wajib pajak secara maksimal agar wajib pajak tidak mengalami kebingungan saat membayar pajak. Menurut Laksono \& Ardiyanto (2011), petugas pajak dituntut untuk memberikan pelayanan yang ramah, adil, dan tegas setiap saat kepada wajib pajak serta dapat memupuk kesadaran masyarakat tentang tanggung jawab membayar pajak.

Peningkatan kualitas dan kuantitas pelayanan diharapkan dapat memberikan kepuasan wajib pajak sebagai pelanggan dibidang perpajakan juga semakin meningkat (Komala et al., 2014). Pelayanan yang berkualitas didefinisikan sebagai suatu pelayanan yang dapat menimbulkan rasa puas bagi konsumen dan selalu dalam batas standar pemenuhan harapan layanan dan harus selalu wajib dilaksanakan. Apabila didefinisikan secara sederhana kualitas dapat diartikan sebagai suatu kondisi dinamis yang berhubungan dengan produk, jasa, proses maupun lingkungan yang dapat memenuhi atau melebihi harapan dari pihak yang menginginkannya (Alabede et al., 2011). Hasil Penelitian yang diperoleh oleh (Awaluddin et al., 2017) menunjukkan bila kualitas pelayanan mempengaruhi secara signifikan pada kepatuhan wajib pajak kendaraan bermotor di Kantor Bersama SAMSAT Kendari. Hasil tersebut didukung oleh Penelitian yang dilakukan oleh penelitian Tresnalyani (2018) yang menunjukkan bahwa kualitas pelayanan berpengaruh positif terhadap kepatuhan wajib pajak dalam membayar pajak kendaraan bermotor di Kantor Bersama SAMSAT Kota Denpasar. Berdasarkan hasil penelitian sebelumnya, maka hipotesis yang diajukan dalam penelitian ini adalah.

$\mathrm{H}_{3}$ : Kualitas pelayanan berpengaruh positif pada kepatuhan wajib pajak kendaraan bermotor di Kantor SAMSAT Kota Denpasar.

Theory of Planned Behaviour menyatakan timbulnya niat atau keinginan untuk berperilaku salah satunya dipengaruhi oleh normative beliefs bahwa seseorang akan memiliki niat untuk berperilaku jika mempunyai kepercayaan terhadap harapan normatif orang lain dan memiliki dorongan untuk mewujudkan harapan tersebut. Sosialisasi perpajakan dapat menjadi motivasi bagi masyarakat untuk patuh dan mau membayar pajak. Pentingnya sosialisasi memberikan pengertian kepada masyarakat dalam membayar pajak, dengan adanya sosialisasi perpajakan masyarakat menjadi mengerti dan paham mengenai manfaat membayar pajak (Winerungan, 2012). Herryanto \& Toly (2013) mengatakan kurangnya pengetahuan dan wawasan pajak karena rendahnya sosialisasi perpajakan akan menyebabkan wajib pajak tidak memahami bagaimana cara melaksanakan kewajiban perpajakan dan pada akhirnya tidak melaksanakan kewajibannya tersebut, hal tersebut akan berdampak pada penerimaan pajak negara. Penelitian yang dilakukan oleh Dharma (2014), menyimpulkan bahwa sosialisasi perpajakan berpengaruh signifikan terhadap Kepatuhan Pajak PKB dan BBNKB di Kantor Bersama SAMSAT Kota Denpasar. Selain itu, Hasil penelitian yang dilakukan Rusmayani dan Supadmi (2017) menemukan bahwa sosilisasi perpajakan berpengaruh positif pada kepatuhan wajib pajak kendaraan bermotor di Kantor Bersama 
SAMSAT Tabanan. Berdasarkan hal tersebut, maka dirumuskan hipotesis sebagai berikut.

$\mathrm{H}_{4}$ : Sosialisasi perpajakan berpengaruh positif pada kepatuhan wajib pajak dalam membayar Pajak Kendararaan Bermotor di Kantor SAMSAT Kota Denpasar.

\section{METODE PENELITIAN}

Lokasi penelitian ini adalah di Kantor Bersama SAMSAT Kota Denpasar yang beralamat di Jalan Cok Agung Tresna Nomor 1 Denpasar. Peneliti memilih lokasi ini karena Kantor Bersama SAMSAT tersebut memiliki jumlah wajib pajak terbanyak dibandingkan dengan delapan kabupaten lainnya yang terdapat di Bali dan jumlah wajib pajak yang melaksanakan kewajiban pajaknya dan menunggak mengalami peningkatan. Objek penelitian dalam penelitian ini adalah kepatuhan wajib pajak dalam membayar pajak kendaraan bermotor di kantor SAMSAT Kota Denpasar.

Populasi yang dimaksud dalam penelitian ini adalah seluruh wajib pajak kendaraan bermotor yang terdaftar pada Kantor SAMSAT Kota Denpasar. Adapun jumlah seluruh wajib pajak kendaraan bermotor yang terdaftar pada Kantor SAMSAT Kota Denpasar adalah 748.113 wajib pajak.

Metode penentuan sampel yang digunakan dalam penelitian ini adalah nonprobability sampling dan teknik accidental sampling. Adapun kriteria sampel dalam penelitian ini adalah: 1) Wajib Pajak Kendaraan Bermotor yang terdaftar di Kantor SAMSAT Bersama Kota Denpasar. 2) Wajib Pajak Kendaraan Bermotor yang mengurus kewajiban pajaknya sendiri dan bukan biro jasa. Besarnya ukuran samapel dihitung dengan menggunakan rumus Slovin, berikut.

$n=\frac{N}{\left(1+N(e)^{2}\right)}$

Keterangan :

$\mathrm{n}=$ Jumlah anggota sampel

$\mathrm{N}=$ Jumlah anggota populasi

$\mathrm{e}=$ Nilai kritis (batas ketelitian, 0,1 )

Perhitungan sampel:

$n=\frac{748.113}{\left(1+784.113(0,1)^{2}\right)}$

$\mathrm{n}=99,99$

$\mathrm{n}=100$ (dibulatkan)

Dengan ukuran populasi (N) adalah 748.113 wajib pajak dengan persen kelonggaran ketidaktelitian karena kesalahan pengambilan sampel yang dapat ditolerir atau diinginkan (0,1). Responden dalam penelitian ini adalah 100 wajib pajak kendaraan bermotor di Kantor Bersama SAMSAT Kota Denpasar.

Uji hipotesis menggunakan regresi linier berganda yaitu untuk menguji pengaruh variabel kesadaran wajib pajak, kualitas pelayanan, sanksi perpajakan dan sosialisasi perpajakan pada kepatuhan wajib pajak dalam membayar pajak kendaraan bermotor, maka model persamaan analisis regresi linear berganda disajikan seperti berikut.

$Y=\alpha+\beta_{1} X_{1}+\beta_{2} X_{2}+\beta_{3} X_{3}+\beta_{4} X_{4}+\varepsilon$

Keterangan : 


$\begin{array}{ll}\mathrm{Y} & : \text { Kepatuhan Wajib Pajak } \\ \mathrm{a} & \text { : Bilangan konstanta } \\ \beta_{1}-\beta_{4} & \text { : Koefisien regresi } \\ \mathrm{X}_{1} & \text { : Kesadaran Wajib Pajak } \\ \mathrm{X}_{2} & \text { :Sanksi Perpajakan } \\ \mathrm{X}_{3} & \text { : Kualitas Pelayanan } \\ \mathrm{X}_{4} & \text { : Sosialisasi Perpajakan } \\ \varepsilon & \text { : Standar error }\end{array}$

\section{HASIL DAN PEMBAHASAN}

Pengukuran rata-rata (mean) merupakan cara paling umum digunakan untuk mengukur nilai sentral dari suatu distribusi data. Sedangkan, standar deviasi merupakan perbedaan nilai data yang diteliti dengan nilai rata-ratanya. Hasil statistik deskriptif dapat dilihat pada Tabel 1, berikut.

Tabel 1. Hasil Uji Statistik Deskriptif

\begin{tabular}{llllll}
\hline Variabel & $\mathrm{N}$ & Minimum & Maximum & Mean & $\begin{array}{l}\text { Std. } \\
\text { Deviasi }\end{array}$ \\
\hline Kesadaran Wajib Pajak $\left(\mathrm{X}_{1}\right)$ & 100 & 5 & 12 & 9,82 & 1,648 \\
Sanksi Perpajakan $\left(\mathrm{X}_{2}\right)$ & 100 & 5 & 16 & 12,77 & 1,979 \\
Kualitas Pelayanan $\left(\mathrm{X}_{3}\right)$ & 100 & 10 & 20 & 16,50 & 2,476 \\
Sosialisasi Perpajakan $\left(\mathrm{X}_{4}\right)$ & 100 & 3 & 12 & 9,98 & 1,537 \\
Kepatuhan Wajib Pajak $(\mathrm{Y})$ & 100 & 3 & 12 & 10,24 & 1,730 \\
\hline
\end{tabular}

Sumber: Data Penelitian, 2019

Pada Tabel 1, diketahui nilai minimum untuk variabel kesadaran wajib pajak $\left(X_{1}\right)$ adalah 5 dan nilai maksimumnya adalah 12. Mean untuk variabel kesadaran wajib pajak adalah 9,82 hal ini berarti rata-rata nilai variabel kesadaran wajib pajak adalah sebesar 9,82 dan standar deviasinya 1,648. Untuk variabel sanksi perpajakan $\left(X_{2}\right)$ nilai minimumnya adalah 5 dan nilai maksimumnya adalah 6. Mean untuk variabel sanksi perpajakan adalah 12,77 hal ini berarti rata-rata nilai variabel sanksi perpajakan adalah sebesar 12,77 dan standar deviasinya 1,979. Untuk variabel kualitas pelayanan $\left(X_{3}\right)$ nilai minimumnya adalah 10 dan nilai maksimumnya adalah 20. Mean untuk variabel kualitas pelayanan adalah 16,50 hal ini berarti rata-rata nilai variabel kualitas pelayanan adalah sebesar 16,50 dan standar deviasinya 2,476.

Untuk variabel sosialisasi perpajakan $\left(X_{4}\right)$ nilai minimumnya adalah 3 dan nilai maksimumnya adalah 12. Mean untuk variabel kualitas pelayanan adalah 9,98 hal ini berarti rata-rata nilai variabel kualitas pelayanan adalah sebesar 9,98 dan standar deviasinya 1,537. Untuk variabel kepatuhan wajib pajak (Y) nilai minimumnya adalah 3 dan nilai maksimumnya adalah 12. Mean untuk variabel kepatuhan wajib pajak adalah 10,24 hal ini berarti rata-rata nilai variabel kepatuhan wajib pajak adalah sebesar 10,24 dan standar deviasinya 1,730.

Analisis regresi linear berganda digunakan untuk mengetahui besarnya pengaruh variabel kesadaran wajib pajak, sanksi perpajakan, kualitas pelayanan, dan sosialissi perpajakan sebagai variabel bebas (independen) pada kepatuhan wajib pajak sebagai variabel terikat (dependen). Adapun hasil dari uji regresi linear berganda dapat dilihat pada Tabel 2, berikut. 
Tabel 2. Hasil Analisis Regresi Linear Berganda

\begin{tabular}{llllll}
\hline \multirow{2}{*}{ Variabel } & \multicolumn{2}{l}{$\begin{array}{l}\text { Unstandardized } \\
\text { Coefficients }\end{array}$} & $\begin{array}{l}\text { Standardized } \\
\text { Coefficients }\end{array}$ & \multirow{2}{*}{$\mathrm{t}$} & \multirow{2}{*}{ Sig. } \\
\cline { 2 - 5 } & $\mathrm{B}$ & $\begin{array}{l}\text { Std. } \\
\text { Error }\end{array}$ & Beta & & \\
\hline Constant & $-1,688$ & 0,689 & & $-2,449$ & 0,016 \\
Kesadaran Wajib Pajak $\left(\mathrm{X}_{1}\right)$ & 0,135 & 0,058 & 0,128 & 2,335 & 0,022 \\
Sanksi Perpajakan $\left(\mathrm{X}_{2}\right)$ & 0,149 & 0,056 & 0,171 & 2,662 & 0,009 \\
Kualitas Pelayanan $\left(\mathrm{X}_{3}\right)$ & 0,175 & 0,042 & 0,251 & 4,206 & 0,000 \\
Sosialisasi Perpajakan $\left(\mathrm{X}_{4}\right)$ & 0,582 & 0,080 & 0,517 & 7,258 & 0,000 \\
Adjusted R Square & 0,773 & & & & \\
F hitung & 85,353 & & & & \\
Sig. F hitung & 0,000 & & & &
\end{tabular}

Pada Tabel 2, dapat diketahui bahwa, persamaan regresi linear berganda menjadi sebagai berikut.

$$
Y=-1,688+0,135 X_{1}+0,149 X_{2}+0,175 X_{3}+0,582 X_{4}+\varepsilon
$$

Berdasarkan hasil uji t dan nilai signifikansi pada variabel kesadaran wajib pajak $\left(X_{1}\right)$ menunjukkan nilai sig lebih kecil dari 0,05, maka dapat disimpulkan bahwa kesadaran wajib pajak $\left(X_{1}\right)$ berpengaruh positif dan signifikan pada kepatuhan wajib pajak $(Y)$. Hasil penelitian ini menunjukkan semakin tinggi tingkat kesadaran dari wajib pajak untuk membayar kewajibannya, maka semakin tinggi pula tingkat kepatuhan dari wajib pajak tersebut. Sedangkan apabila tingkat kesadaran wajib pajak untuk membayar kewajiban pajaknya rendah, maka semakin rendah pula tingkat kepatuhan dari wajib pajak tersebut. Sehingga dengan demikian hipotesis pertama penelitian ini dapat diterima.

Hasil jawaban responden menunjukkan pernyataan wajib pajak sadar bahwa Pajak Kendaraan Bermotor merupakan bentuk partisipasi dalam menunjang pembangunan daerah memperoleh skor rata-rata tertinggi sebesar 3,49 dan pernyataan wajib pajak sadar bahwa Pajak Kendaraan Bermotor ditetapkan dengan Undang-Undang tentang Pajak Daerah dan dapat dipaksakan memperoleh skor rata-rata terendah sebesar 3,14. Hal ini menunjukkan kesungguhan dan keinginan wajib pajak dalam melaksanakan kewajibannya tercermin dari pemahaman wajib pajak terhadap fungsi Pajak Kendaraan bermotor yaitu sebagai salah satu yang menunjang pembangunan daerah. Hal ini menunjukkan bahwa keyakinan akan hasil dari perilaku wajib pajak dapat dipengaruhi oleh adanya kesadaran wajib pajak untuk berperilaku patuh. Hal tersebut sejalan dengan Theory of Planned Behavior yaitu Behavioral beliefs yang menyatakan bahwa indvidu memiliki keyakinan akan hasil dari suatu perilaku dan evaluasi dari hasil tersebut. Hasil penelitian ini juga sejalan dengan penelitian yang dilakukan oleh Pujiasti (2016) yang menyatakan bahwa kesadaran wajib pajak berpengaruh terhadap kepatuhan wajib pajak dalam membayar pajak kendaraan bermotor pada Kantor SAMSAT Kota Bogor. Penelitian Nirajenani (2018) juga membuktikan bahwa kesadaran wajib pajak berpengaruh positif dan signifikan terhadap kepatuhan wajib pajak dalam membayar pajak kendaraan bermotor di Kantor SAMSAT Gianyar.

Berdasarkan hasil uji $\mathrm{t}$ dan nilai signifikansi pada variabel sanksi perpajakan $\left(\mathrm{X}_{2}\right)$ menunjukkan nilai sig lebih kecil dari 0,05, maka dapat 
disimpulkan bahwa sanksi perpajakan $\left(\mathrm{X}_{2}\right)$ berpengaruh positif dan signifikan pada kepatuhan wajib pajak (Y). Hasil penelitian ini menunjukkan semakin tinggi sanksi perpajakan, maka semakin tinggi pula tingkat kepatuhan dari wajib pajak tersebut. Sedangkan apabila sanksi perpajakan rendah, maka semakin rendah pula tingkat kepatuhan dari wajib pajak tersebut. Berarti hipotesis kedua penelitian ini dapat diterima.

Jawaban responden menunjukkan item pernyataan sanksi pajak harus dikenakan kepada pelanggar tanpa toleransi memperoleh skor rata-rata tertinggi sebesar 3,37 dan pernyataan sanksi administrasi yang dikenakan bagi pelanggar aturan pajak sangat ringan memperoleh skor rata-rata terendah sebesar 2,8. Hal ini menunjukkan bahwa dengan mengenakan sanksi pajak kepada pelanggar tanpa toleransi dapat menjamin wajib pajak untuk patuh terhadap sanksi yang dibuat oleh pemerintah. Hasil tersebut didukung oleh Theory of Planned Behavior dimana sanksi administrasi terkait dengan perceived behavioral control karena sanksi dibuat untuk mendukung wajib pajak agar mematuhi peraturan administrasi perpajakan. Dengan mengenakan sanksi kepada pelanggar tanpa toleran merupakan jaminan bahwa ketentuan peraturan perundangan-undangan perpajakan akan ditaati. Kepatuhan wajib pajak akan ditentukan berdasarkan presepsi wajib pajak tentang seberapa kuat sanksi perpajakan yang mendukung perilaku wajib pajak untuk taat pajak. Hasil penelitian ini juga didukung oleh penelitian yang dilakukan Ilhamsyah et al., (2016) yang menemukan bahwa sanksi pajak berpengaruh signifikan terhadap kepatuhan wajib pajak kendaraan bermotor yang terdaftar di Kantor Bersama SAMSAT Kota Malang. Penelitian dari Angraini (2018) juga membuktikan bahwa sanksi perpajakan berpengaruh positif terhadap kepatuhan wajib pajak di Kantor Bersama SAMSAT Kota Palembang.

Berdasarkan hasil uji $\mathrm{t}$ dan nilai signifikansi pada variabel kualitas pelayanan $\left(X_{3}\right)$ menunjukkan nilai sig lebih kecil dari 0,05, maka dapat disimpulkan bahwa kualitas pelayanan $\left(X_{3}\right)$ berpengaruh postif dan signifikan pada kepatuhan wajib pajak (Y). Hasil penelitian ini menunjukkan semakin tinggi kualitas pelayanan yang diberikan, maka semakin tinggi pula tingkat kepatuhan dari wajib pajak tersebut. Sed angkan apabila kualitas pelayanan yang diberikan rendah, maka semakin rendah pula tingkat kepatuhan dari wajib pajak tersebut. Berarti hipotesis ketiga penelitian ini dapat diterima.

Jawaban responden menunjukkan pernyataan petugas Kantor Bersama SAMSAT Denpasar memberikan layanan tanpa melihat status sosial kepada wajib pajak memperoleh skor rata-rata tertinggi sebesar 3,36 dan pernyataan kondisi gedung, teknologi dan pelayanan Kantor Bersama SAMSAT Denpasar memadai memperoleh skor rata-rata terendah sebesar 3,32. Hal ini menunjukan upaya petugas untuk menigkatkan kepatuhan wajib pajak dengan memberikan pelayanan tanpa memandang status sosial wajib pajak baik dan saranana dan prasarana perlu ditingkatkan. Hasil penelitian ini sejalan dengan Theory of planned behavior yang digunakan untuk menjelaskan perilaku wajib pajak dalam memenuhi kewajiban perpajakan yaitu Normative beliefs, dimana seseorang akan memiliki keinginan untuk berperilaku jika memiliki kepercayaan mengenai harapan normatif orang lain dan memiliki dorongan untuk mewujudkan harapan tersebut. Upaya dalam peningkatan kepatuhan 
wajib pajak yang dilakukan oleh petugas yaitu dengan tidak memandang status sosial wajib pajak dalam memberikan pelayanan merupakan salah satu bentuk meningkatkan kualitas pelayanan yang baik kepada wajib pajak. Hasil penelitian ini juga didukung oleh hasil penelitian yang diakukan oleh (Awaluddin et al., 2017) yang menunjukkan bahwa bila kualitas pelayanan memengaruhi secara signifikan pada kepatuhan wajib pajak kendaraan bermotor di Kantor Bersama SAMSAT Kendari. Hasil tersebut didukung juga oleh penelitian yang dilakukan Tresnalyani (2018) yang menunjukkan bahwa kualitas pelayanan berpengaruh positif terhadap kepatuhan wajib pajak dalam membayar pajak kendaraan bermotor di Kantor Bersama SAMSAT Kota Denpasar.

Variabel sosialisasi perpajakan $\left(\mathrm{X}_{4}\right)$ menunjukkan nilai sig lebih kecil dari 0,05, maka dapat disimpulkan bahwa, sosialisasi perpajakan $\left(\mathrm{X}_{4}\right)$ berpengaruh positif dan signifikan pada kepatuhan wajib pajak (Y) Hasil penelitian ini menunjukkan semakin sering sosialisasi perpajakan yang diberikan, maka tingkat kepatuhan dari wajib pajak semakin meningkat. Sedangkan apabila sosialissi perpajakan yang diberikan jarang, maka semakin rendah pula tingkat kepatuhan dari wajib pajak tersebut. Berarti hipotesis keempat peneltian ini dapat diterima.

Hasil jawaban responden menunjukkan pernyataan petugas menguasai materi mengenai penjelasan dan penyuluhan tentang PKB memperoleh skor rata-rata tertinggi sebesar 3,43 dan pernyataan kantor SAMSAT mengadakan kegiatan penyuluhan tentang PKB memperoleh skor rata-rata terendah sebesar 3,2. Hasil tersebut menunjukkan bahwa dengan menguasai materi penyuluhan tentang PKB dengan baik dapat memberikan pengertian dan pemahaman kepada wajib pajak mengenai manfaat membayar pajak. Sosialisasi perpajakan dapat menjadi motivasi bagi masyarakat untuk patuh dan mau membayar pajak. Hasil penelitian ini mendukung Theory of Planned Behaviour, dimana timbulnya niat atau keinginan untuk berperilaku salah satunya dipengaruhi oleh normative beliefs bahwa seseorang akan memiliki niat untuk berperilaku jika mempunyai kepercayaan terhadap harapan normatif orang lain dan memiliki dorongan untuk mewujudkan harapan tersebut. Hasil penelitian ini juga didukung oleh Penelitian yang dilakukan oleh Dharma (2014), menyimpulkan bahwa sosialisasi perpajakan berpengaruh signifikan terhadap Kepatuhan Pajak PKB dan BBNKB di Kantor Bersama SAMSAT Kota Denpasar. Selain itu, hasil penelitian yang dilakukan Rusmayani \& Supadmi (2017), menemukan bahwa sosilisasi perpajakan berpengaruh positif pada kepatuhan wajib pajak kendaraan bermotor di Kantor Bersama SAMSAT Tabanan.

Koefisien determinasi $\left(\mathrm{R}^{2}\right)$ digunakan untuk mengukur kemampuan variabel bebas (independen) yaitu kesadaran wajib pajak, sanksi perpajakan, kualitas pelayanan, dan sosialisasi perpajakan dalam menjelaskan variabel terikat (dependen) yakni kepatuhan wajib pajak. Berdasarkan Tabel 2, besarnya adjusted $R$ square adalah 0,773 . Artinya 77,3 persen kepatuhan wajib pajak dipengaruhi oleh variabel kesadaran wajib pajak, sanksi perpajakan, kualitas pelayanan, dan sosialisasi perpajakan, sedangkan sisanya 22,7 persen dipengaruhi oleh variabel lain yang tidak dimasukkan dalam penelitian. 


\section{SIMPULAN}

Penelitian ini mampu memberikan tambahan informasi dalam kajian empiris tentang kesadaran wajib pajak, sanksi perpajakan, kualitas pelayanan dan sosialisasi perpajakan serta pengaruhnya pada kepatuhan wajib pajak khususnya dalam membayar pajak kendaraan bermotor. Hasil analisis dalam penelitian ini menunjukkan bahwa kesadaraan wajib pajak, sanksi perpajakan, kualitas pelayanan dan sosialisasi perpajkan berpengaruh positif pada kepatuhan wajib pajak. Hasil penelitian ini dapat memberikan masukan dan pertimbangan kepada pemerintah mengenai pengaruh kesadaran wajib pajak, sanksi perpajakan, kualitas pelayanan dan sosialisasi perpajakan terhadap kepatuhan wajib pajak dalam membayar pajak kendaraan bermotor. Bagi peneliti selanjutnya dengan memperhatikan keterbatasan-keterbatasan yang terdapat dalam penelitian ini, diharapkan melakukan penelitian serupa agar dapat memperbaiki keterbatasan dalam penelitian ini yaitu dengan menambah variabel independen lainnya yang tidak terdapat dalam penelitian ini seperti pemeriksaan pajak, penagihan pajak, tarif pajak, dan sistem administrasi yang terkait dengan kepatuhan wajib pajak dalam membayar pajak kendaraan bermotor. Bagi Kantor Bersama SAMSAT Kota Denpasar agar dapat meningkatkan ketegasan penerapan sanksi perpajakan dengan memberikan sanksi administrasi dan sanksi pidana kepada wajib pajak yang melakukan pelanggaran dengan lebih tegas dan tanpa toleransi. Bagi para wajib pajak agar lebih menyadari bahwa pajak kendaraan bermotor merupakan bentuk partisipasi dalam menunjang pembangunan daerah dan penundaan pembayaran pajak sangat merugikan daerah.

\section{REFERENSI}

Alabede, J. O., Ariffin, Z. B. Z., \& Indris, K. M. (2011). Determinants of Tax Compliance Behaviour: A Proposed Model for Nigeria. International Research Journal of Finance and Economics, 78(78).

Angraini, D., \& Khairani, S. (2018). Pengaruh Kesadaran Wajib Pajak dan Sanksi Pajak Terhadap Kepatuhan Membayar Pajak Kendaraan Bermotor (Studi Kasus pada WPOP Kendaraan Bermotor di Kota Palembang). Akuntansi STIE Multi Data Palembang, 1-14.

Astana, I. W. S., \& Lely Aryani Merkusiwati, N. K. (2017). Pengaruh Penerapan Sistem Administrasi Perpajakan Modern Dan Kesadaran Wajib Pajak Pada Kepatuhan Wajib Pajak. E-Jurnal Akuntansi Universitas Udayana, 181, 23028556.

Awaluddin, I., Nurnaluri, S., \& Damayanti, W. O. R. (2017). Pengaruh Kualitas Pelayanan dan Kepuasan Wajib Pajak Terhadap Kepatuhan Membayar Pajak Kendaraan Bermotor (Studi pada Kantor Besama SAMSAT Kendari). Jurnal Akuntansi Dan Keuangan, II, 109-122.

Dharma, G. P. E., \& Suardana, K. A. (2014). Fakultas Ekonomi dan Bisnis Universitas Udayana ( Unud ), Bali , Indonesia negara untuk mengatasi masalah sosial, meningkatkan kesejahteraan dan. E-Jurnal Akuntansi Universitas Udayana, 1, 340-353.

Herryanto, M., \& Toly, A. A. (2013). Pengaruh Kesadaran Wajib Pajak , Kegiatan Sosialisasi Perpajakan, dan Pemeriksaan Pajak terhadap Penerimaan Pajak 
Penghasilan di KPP Pratama Surabaya Sawahan. Tax and Accounting Review, 1.

Ilhamsyah, R., Endang, M. G. W., \& Dewantara, R. Y. (2016). Pengaruh Pemahaman dan Pengetahuan Wajib Pajak Tentang Peraturan Perpajakan, Kesadaran Wajib Pajak, Kualitas Pelayanan, dan Sanksi Perpajakan Terhadap Kepatuhan Wajib Pajak Kendaraan Bermotor (Studi SAMSAT Kota Malang).

Jotopurnomo, C., \& Mangoting, Y. (2013). Pengaruh kesadaran wajib pajak, kualitas pelayanan, dan sanksi perpajakan terhadap kepatuhan wajib pajak orang pribadi di Surabaya. Accounting and Tax Review, 1, 6. https://doi.org/10.1016/j.apsusc.2017.11.151

Komala, K. C., Suhadak, \& Endang, M. G. W. (2014). Pengaruh Kualitas Pelayanan Perpajakan Terhadap Kepatuhan Wajib Pajak Badan (Studi Pada Kantor Pelayanan pajak Madya Malang), 1-9.

Kurniawan, A. (2006). Transformasi Pelayanan dan Publik. Yogyakarta: Pembaharuan.

Laksono, J. P., \& Ardiyanto, D. H. M. (2011). Analisis Faktor-Faktor yang Mempengaruhi Kepatuhan Wajib Pajak Badan pada Perusahaan Industri Manufaktur di Semarang.

Mardiasmo. (2016). Perpajakan Edisi Revisi Tahun 2016. Yogyakarta:Penerbit Andi.

Nirajenani, C. I. P., \& Aryani, N. K. L. (2018). Faktor-faktor yang Mempengaruhi Kepatuhan Wajib Pajak dalam Membayar Pajak Kendaraan Bermotor, 24, 339-369. https://doi.org/https://doi.org/10.24843/EJA.2018.v24.i01.p13

Pujiasti, S. F. (2016). Pengaruh Kesadaran Wajib Pajak dan Kualitas Pelayanan Pajak Terhadap Kepatuhan Wajib Pajak dalam Membayar Pajak Kendaraan Bermotor (Studi Kasus pada Kantor SAMSAT Kota Bogor).

Putri, A. R. S., \& Jati, I. K. (2013). Faktor-faktor yang Mempengaruhi kepatuhan Wajib Pajak Dalam Membayar Pajak Kendaraan Bermotor di Denpasar. EJurnal Akuntansi Universitas Udayana, (2011), 661-677.

Rusmayani, N. M. L., \& Supadmi, N. L. (2017). Pengaruh Sosialisasi, Pengetahuan, Sanksi Dan Kualitas Pelayanan Pada Kepatuhan Wajib Pajak Kendaraan Bermotor. E-Jurnal Akuntansi Universitas Udayana, Vol.20, No(ISSN: 2302-8556), 173-201.

Tiraada, T. A. M. (2013). Kesadaran Perpajakan, Sanksi Pajak, Sikap Fiskus Terhadap Kepatuhan WPOP Di Kabupaten Minahasa Selatan, 1(3), 999_ 1008.

Tresnalyani, N. K. M., \& Jati, I. K. (2018). Pengaruh Kualitas Pelayanan, Pengetahuan Perpajakkan dan Biaya Kepatuhan pada Kepatuhan Wajib Pajak Kendaraan Bermotor. E-Jurnal Akuntansi Universitas Udayana, 24, 578605. https://doi.org/https://doi.org/10.24843/EJA.2018.v24.i01.p22 Pengaruh

Utama, I. W. M. (2013). Pengaruh kualitas pelayanan, sanksi perpajakan dan biaya kepatuhan terhadap kepatuhan wajib pajak. Jurnal Akuntansi, 2(2), 452-470.

Webley, P., Robben, H., Elffers, H., Hessing, D., \& An, T. E. (1991). Book review, 13(1902), 187-190. 
Winerungan, O. L. (2012). Sosialisasi Perpajakan, Pelayanan Fiskus, dan Sanksi Perpajakan Terhadap Kepatuhan WPOP di KPP Manado dan KPP Bitung, 1(3), 960-970. 